\title{
Pemanfaatan Entomopatogenik Fungi Lokal untuk menjaga Kwalitas Sayuran Organik Brastagi
}

\section{Oleh \\ Sularno}

\author{
Dosen KOPERTIS WILAYAH I FKIP Biologi UISU- Medan
}

\begin{abstract}
ABSTRAKS
Tujuan penelitian adalah untuk memanfaatkan potensi fungi entomopatogen yang ada disekitar lahan tanaman sayuran Brastagi dalam pengendalian hama-hama yang menyerang sayur, sehingga bisa digunakan menjaga kwalitas sayuran organic. Metode yang digunakan adalah eksplorasi jamur dengan umpan larva serangga Tenebrio molitor,identifikasi makroskopik terhadap jamur yang ditemukan serta mendeskripsikan manfaat fungi-fungi tersebut dalam perananya sebagai pengendalian hama terpadu secara hayati. Pada tahap lanjut jamur-jamur tersebut dapat dikembangkan untuk diaplikasikan di lapangan sehingga petani bisa mengendalikan hama sayuran tanpa penggunaan pestisida.
\end{abstract}

Keyword: Jamur entomopatogen, kwalitas sayur organic, Tenebrio molitor

\section{PENDAHULUAN}

Pestisida digunakan secara luas dalam produksi pertanian.Pestisida berfungsi untuk mencegah atau produksi tanaman dan menjaga kwalitas produk tanaman. Meskipun regulasi penggunaan mengendalikan hama, penyakit, gulma dan pathogen tanaman lainnya sebagai upaya mengurangi kehilangan pestisida diatur dengan sangat ketat, namun perhatian terhadap dampak negative pestisida pada kesehatan manusia dari pestisida yang terpapar maupun residu pada makanan dan air minum terus diteliti dan dikembangkan ( Damalas, 2011).

Seiring dengan meningkatanya kesadaran masyarakat akan pentingnya kesehatan dan bahayanya pestisida, maka sayuran organik bebas pestisida menjadi alternatif penting untuk menciptakan masyarakat yang sehat lewat konsumsi sayuran dan buah. Brastagi, sebagai gerbang eksport sayur dan buah sumatera utara punya potensi untuk menjadi sentra produksi sayur organik, dengan lahan seluas 25,96 ha, saat ini sedang digalakkan budidaya sayuran organik baik oleh lembaga penelitian maupun masyarakat setempat (Badan Penelitian dan Pengembangan Pertanian, 2013). Tantangan yang dihadapi para pelaku budidaya sayur organik adalah meningkatnya serangan hama dan lahan pertanian yang selama ini menggunakan pupuk sintesis.

Alternatif pengendalian hama untuk sayuran organic adalah pemanfaatan musuh alami. Diantara musuh alami pengendali hama adalah jamur pathogen pada serangga. Secara umum jamur pathogen pada serangga diantaranya adalah Metarhizium anisopliae, Beauveria bassiana, Nomuraea rileyi, Paecilomyces farinosus and Paecilomyces fumosoroseus(Takhur dan Sandhu, 2010), Lagenidium, Coelomomyces, Conidiobolus, Entomophaga, Entomophthora, Erynia, Neozygites, Pandora, Zoophthora, Cordyceps,

Hypocrella, Torrubiella, Aschersonia, Hirsutella, Tolypocladium, dan Verticillium (Pell dan Shah, 2003). Eksplorasi, budidaya dan pemanfaatan jamur pathogen tersebut belum banyak 
dilakukan. Oleh karena itu perlu adanya penelitian intensif untuk eksplorasi dan mengetahui keragaman jamur pathogen pengendali hama yang ada di Brastagi dan pemanfaatanya dalam peningkatan kwalitas sayuran organic.

\section{METODOLOGI}

Penelitian ini menggunakan metode eksplorasi dengan umpan larva Tenebrio molitor, bertujuan untuk mengetahui keragaman jamur entomopatogen yang ada di lahan tananaman sayuran di Brastagi. Dalam penelitian ini menggunakan strategi pendekatan sebagai berikut:

\section{Tahap eksplorasi}

1. Pertama penelitian melakukan eksplorasi jamur yang ada ditanah sekitar akar tanaman dengan kedalaman 5 sampai $15 \mathrm{~cm}$. Sampel tanah diambil sesuai dengan penetapan sampling. Tanah kemudian dimasukkan kedalam plastikdan dicampur hingga homogen.

2. Sampel tanah yang didapatkan diletakkan ke dalam wadah plastik, diisi kira-kira setengah dari volume wadah.

3. Sebelum ulat Tenebrio molitor dimasukkan, tanah di dalam wadah dilembabkan dengan menambahkan air secukupnya.

4. Meletakkan ulat Tenebrio molitor di permukaan tanah dalam wadah, ulat yang dimasukkan adalah ulat yang baru molting (ganti kulit) yaitu yang berwarna putih.

5. Selanjutnya wadah ditutup menggunakan kain kasa agar ulat tidak keluar dari wadah, kemudian diinkubasikan selama 1 sampai 2 minggu di tempat gelap agar ulat perangkap bergerak aktif, sehingga mudah kontak dengan jamur entomopatogen yang berada di dalam sampel tanah tersebut

\section{.2. Tahapan isolasi}

1. UlatTenebrio molitor yang terinfeksi jamur diisolasi dengan cara menanamkan sampel jaringan terinfeksi pada media Potato Dekstrose Agar (PDA) dan diinkubasikan selama 5 sampai 7 hari

2. Isolasi dilakukan dengan cara mencelupkan sampel jaringan terinfeksi (ulat Tenebrio molitor) beberapa saat ( \pm 3 menit) ke dalam larutan clorox, alkohol, kemudian dibilas dengan aquadest steril.

3. Jamur yang tumbuh pada media diidentifikasi dan ditularkan kembali (reinokulasi) pada serangga uji.

4. Jamur entomopatogen yang virulen diperbanyak dan dikembangkan untuk pengendalian di lapangan

\section{HASIL DAN PEMBAHASAN}

\section{Tahap Eksplorasi}

Eksplorasi jamur yang ada ditanah sekitar akar tanaman dengan kedalaman 5 sampai $15 \mathrm{~cm}$. Sampel tanah diambil dari sentra perkebunan tanaman holtikultura yang didominasi tanaman kol/kubis . Lokasi Pengambilan sampel tanah di desa Gajah, Kecamatan Simpang Empat 
Kabupaten Tanah Karo Sumatera Utara. Sampel tanah diambil dari lahan tanaman kubis, sawi, brokoli, buncis dan tomat. Masing-masing lahan diambil 7 sampel tanah secara diagonal

Sampel tanah yang didapatkan diletakkan ke dalam wadah plastik, diisi kira-kira setengah dari volume wadah. Sebelum ulat Tenebrio molitor dimasukkan, tanah di dalam wadah dilembabkan dengan menambahkan air secukupnya. Meletakkan ulat Tenebrio molitor di permukaan tanah dalam wadah, ulat yang dimasukkan adalah ulat yang baru molting (ganti kulit) yaitu yang berwarna putih Selanjutnya wadah ditutup menggunakan kain kasa agar ulat tidak keluar dari wadah, kemudian diinkubasikan selama 1 sampai 2 minggu di tempat gelap agar ulat perangkap bergerak aktif, sehingga mudah kontak dengan jamur entomopatogen yang berada di dalam sampel tanah tersebut. Hasil eksplorasi jamur dari masing-masing dapat dilihat pada table berikut.

Tabel 1. Jenis lahan tanaman sayuran dan ulat Tenebrio molitor yang terinfeksi jamur

\begin{tabular}{|l|l|l|l|c|}
\hline No & Tanah dari lahan tanaman & Kondisi Ulat & Jenis Jamur & Frekwensi \\
& & Tenebrio molitor & & \\
\hline 1 & Kubis & terinfeksi & Beuveria bassiana & 2 \\
\cline { 4 - 5 } & & & Metarhizium anisopliae & 1 \\
\hline 2 & Sawi putih & terinfeksi & Beuveria bassiana & 2 \\
\cline { 4 - 5 } & & & Metarhizium anisopliae & 8 \\
\cline { 4 - 5 } & & & & 1 \\
\hline 4 & Bunga kol & terinfeksi & Beuveria bassiana & 1 \\
\cline { 4 - 5 } & & & Metarhizium anisopliae & 5 \\
\hline 5 & Tomat/cabai & terinfeksi & Beuveria bassiana & 1 \\
\cline { 4 - 5 } & & & Metarhizium anisopliae & 3 \\
\cline { 4 - 5 } & & \multirow{2}{*}{ Tidak terinfeksi } & - & - \\
\hline
\end{tabular}

Dari table 2 terlihat bahwa hampir semua sumber tanah mengandung jamur entomopatogenik fungi dan dari lahan sawi putih yang paling banyak frekwensi terinfeksi. Sedang tanah dari tomat dan cabai tidak ada ulat yang terinfeksi. Sebagai informasi tanah yang diambil dari kebun kubis, sawi putih, bunga kol dan buncis adalah kebun yang tidak lagi dirawat dan diperlakukan dengan pestisida karena merupakan lahan pasca panen. Sehingga jumlah serangga cukup banyak terdapat dilahan. Sedang tanah dari tanaman tomat/ cabai merupakan kebun yang masih aktif dirawat karena dalam fase pertumbuhan dan memasuki fase reproduktif atau munculnya bunga dan buah. Kebun yang masih intensif dirawat dengan perlakuan penyemprotan pestisida. Intensitas penyemprotan pestisida dalam satu minggu sebanyak 3 sampai 4 kali. 
2. Tahap Isolasi

UlatTenebrio molitor yang terinfeksi jamur diisolasi dengan cara menanamkan sampel jaringan terinfeksi pada media Potato Dekstrose Agar (PDA) dan diinkubasikan selama 5 sampai 7 hari. Isolasi dilakukan dengan cara mencelupkan sampel jaringan terinfeksi (ulat Tenebrio molitor) beberapa saat ( \pm 3 menit) ke dalam larutan clorox, alkohol, kemudian dibilas dengan aquadest steril. Dikeringkan dengan tissue steril dan diletakkan diatas kertas saring lembab steril. Konidia jamur entomopatogenik yang keluar dari tubuh larva dibiakkan pada medium PDA menggunakan jarum ose.

3. Pemanfaatan Entomopatogenik Fungi

Salah satu keuntungan penggunaan cendawan B. bassiana sebagai bioinsektisida adalah cendawan ini relatif mudah diperbanyak (diproduksi) pada berbagai jenis media (substrat). Beberapa jenis media (substrat) yang telah digunakan untuk perbanyakan konidia B. bassiana antara lain beras, jagung, gandum, kedelai, dan kentang.

\section{KESIMPULAN DAN SARAN}

\section{DAFTAR PUSTAKA}

Badan Penelitian dan Pengembangan Pertanian. 2013. Jakarta Litbang Pertanian.htm e-mail: info@litbang.deptan.go.id

Bale,J.S; J.C. Van Lenteren; and F. Bigler. 2008. Biological Control and sustainable food Production. Philos. Trans.R.Soc.Lond. B. Biol.Sci.

Blomquist G.J., and Vogt R.G., 2003, Biosynthesis and detection of pheromones and plant volatiles — introduction and overview, In: Blomquist G.J., and Vogt R.G. (eds.), Insect Pheromone Biochemistry and Molecular Biology, Elsevier Academic Press, London, pp. $137-200$

Damalas, Christos A and Ilias G. Eleftherohorinos 2011. Pesticide Exposure, Safety Issues, and Risk Assessment IndicatorsInt J Environ Res Public Health. 2011 May; 8(5): 14021419. 
Khan, Sehroon et al. 2012. Entomopathogenic Fungi as Microbial Biocontrol Agen.Molecular Plant Breeding, 2012, Vol. 3, No. 7

Pell, J.K and Shah, P.A. 2003. Entomopathogenic fungi as biological control agents. Appl Microbial Biotechnol (2003)

Roberts D.W., and St. Leger R.J., 2004, Metarhizium spp., cosmopolitan insect-pathogenic fungi: mycological aspects, Adv. Appl. Microbiol., 54: 1-70

Takhur, Rupesh and Sandhu,Sardul S. 2009. Distribution, occurrence and natural intervertebrate host of indigenous entomopathogenic fungi of Central India. Indian J Microbiol (March 2010) 50(1) : 8996

Wraight S.P., and Carruthers R.I., 1999, Production, delivery, and use of mycoinsecticides for control of insect pests of field crops. In: Hall F.R., and Menn, J.J. (eds.), Biopesticides: Use and delivery, Humana Press, Totowa, New Jersey, pp.233-269 